\title{
Revisiting the disappearance of terrestrial dissolved organic matter in the ocean: a $\delta^{13} \mathrm{C}$ study
}

\author{
K. Lalonde ${ }^{1}$, A. V. Vähätalo ${ }^{2,3}$, and Y. Gélinas ${ }^{1}$ \\ ${ }^{1}$ GEOTOP and Department of Chemistry and Biochemistry, Concordia University Montreal, Quebec, Canada \\ ${ }^{2}$ Department of Bio- and Environmental Science, University of Helsinki, Finland \\ ${ }^{3}$ present address: Department of Biological and Environmental Science, University of Jyväskylä, Finland \\ Correspondence to: Y. Gélinas (yves.gelinas@concordia.ca)
}

Received: 11 October 2013 - Published in Biogeosciences Discuss.: 1 November 2013

Revised: 30 May 2014 - Accepted: 3 June 2014 - Published: 15 July 2014

\begin{abstract}
Organic carbon (OC) depleted in ${ }^{13} \mathrm{C}$ is a widely used tracer for terrestrial organic matter $(\mathrm{OM})$ in aquatic systems. Photochemical reactions can, however, change $\delta^{13} \mathrm{C}$ of dissolved organic carbon (DOC) when chromophoric, aromatic-rich terrestrial $\mathrm{OC}$ is selectively mineralized. We assessed the robustness of the $\delta^{13} \mathrm{C}$ signature of DOC $\left(\delta^{13} \mathrm{C}_{\mathrm{DOC}}\right)$ as a tracer for terrestrial $\mathrm{OM}$ by estimating its change during the photobleaching of chromophoric DOM (CDOM) from 10 large rivers. These rivers cumulatively account for approximately one-third of the world's freshwater discharge to the global ocean. Photobleaching of CDOM by simulated solar radiation was associated with the photochemical mineralization of 16 to $43 \%$ of the DOC and, by preferentially removing compounds depleted in ${ }^{13} \mathrm{C}$, caused a 1 to $2.9 \%$ enrichment in $\delta^{13} \mathrm{C}$ in the residual DOC. Such solarradiation-induced photochemical isotopic shift could bias the calculations of terrestrial OM discharge in coastal oceans towards the marine end-member. Shifts in terrestrial $\delta^{13} \mathrm{C}_{\mathrm{DOC}}$ should be taken into account when constraining the terrestrial end-member in global calculation of terrestrially derived DOM in the world ocean.
\end{abstract}

\section{Introduction}

The oceanic dissolved organic carbon (DOC) pool is large $\left(662 \times 10^{15} \mathrm{~g} \mathrm{OC}\right.$; Hansell et al., 2009), representing a quantity of carbon that is approximately equal to that of carbon dioxide in the atmosphere and terrestrial plant biomass (Hedges, 2002). The turnover of OC within the oceanic reservoir is supported by marine and continental photosyn- thesis, with vascular plant detritus and soil organic matter mainly transported to the ocean by continental erosion and riverine discharge. Apportioning these sources is challenging since oceanic dissolved organic matter (DOM) has a complex, highly altered structure, consisting mainly of relatively small molecules in fairly uniform and very dilute concentrations (Benner et al., 1997). Most evidence points to a nearly purely marine origin for oceanic DOM, as indicated by (1) its marine-like $\delta^{13} \mathrm{C}$ signature (Bauer, 2002; Druffel et al., 1992), (2) the low abundance or absence of terrestrially derived molecular biomarkers within the DOM pool (Opsahl and Benner, 1997; Ogawa and Tanoue, 2003) and (3) the compositional and optical dissimilarities between riverine and seawater DOM (Blough and Del Vecchio, 2002).

Though oceanic DOM is predominantly marine-like, there is evidence that a small yet non-negligible component of DOM has a terrestrial origin. Studies using resin and ultrafiltration-isolated lignin molecules have shown that the terrestrial component varies between 4 and $10 \%$ of the isolated fractions of DOM (Opsahl and Benner, 1997; MeyersSchulte and Hedges, 1986). These are likely underestimations since solar-radiation-induced photochemical reactions break apart large aromatic-rich molecules like lignin, tannin and cutin (Hernes and Benner, 2003; Dittmar et al., 2007; Vähätalo et al., 1999) into molecular fragments that can be difficult to isolate from seawater's salty matrix (too hydrophilic for hydrophobic resins or too small for ultrafiltration) and identify as terrestrial compounds using current analytical methods (Rossel et al., 2013).

Optical parameters (absorbance and fluorescence) that are specific to riverine DOM are also particularly susceptible 
to photochemical transformation since the light-absorbing, chromophoric riverine DOM components are selectively removed upon exposure to UV radiation in a process called photobleaching (Blough and Del Vecchio, 2002; Helms et al., 2008). Photobleaching of terrestrial DOM is associated with the photochemical mineralization of DOC, acting as a partial sink for terrestrial DOC (Moran et al., 2000). The residual non-mineralized fraction of photobleached terrestrial DOM has optical properties that are similar to marine DOM; its terrestrial origin cannot be fully recognized using the currently available optical methods (Helms et al., 2008; Vähätalo and Wetzel, 2008; Spencer et al., 2009). On river-influenced continental margins where dissolved lignin phenols are strongly correlated to the spectral slope coefficient of chromophoric DOM (CDOM) between 275 and $295 \mathrm{~nm}\left(S_{275-295}\right)$, simple spectrophotometric measurements of the slope can be used as a spectral tracer for terrestrial DOM (Fichot and Benner, 2012). However, such models assume that the rate and extent of degradation of the chromophoric and non-chromophoric components are similar, which is likely not the case in extensively photodegraded systems such as oceanic waters.

Stable isotopes of carbon are typically used to trace terrestrial DOM in coastal, estuarine and marine systems since they are thought to incur little to no change in their isotopic signature upon partial OC degradation (Druffel et al., 1992; Raymond and Bauer, 2001a, b; Maher and Eyre, 2011). Photochemical transformations have, however, been shown to shift the stable isotope signature of DOC derived from a plant leachate or collected from a humic lake and three rivers of different size (Osburn et al., 2001; Vähätalo and Wetzel, 2008; Spencer et al., 2009; Opsahl and Zepp, 2001).

Direct (complete mineralization to $\mathrm{CO}_{2}$ ) or indirect (increase in the bioavailability of DOC followed by rapid biological mineralization to $\mathrm{CO}_{2}$ ) photochemical transformations are important pathways in the mineralization of terrestrial DOM (Miller and Zepp, 1995; Spencer et al., 2009; Mopper et al., 1991). Together, these processes can possibly explain the removal of a very large fraction of riverine DOC (Obernosterer and Benner, 2004; Vähätalo and Wetzel, 2008). However, the remaining, non-photoreactive and biologically recalcitrant DOC, representing between 3 and $>20 \%$ of the global riverine input, is still large enough to support as much as half the steady-state turnover of oceanic DOC $\left(0.1 \times 10^{15} \mathrm{~g} \mathrm{C} \mathrm{yr}^{-1}\right)$ (Williams and Druffel, 1987). Thus it remains puzzling that terrestrial DOM would account for a negligible fraction of oceanic DOM. It is possible that riverine DOM remains in oceanic waters but is altered beyond recognition through photodegradation and bacterial relabeling during passage in the microbial loop, allowing for it to escape from the analytical windows of traditional measurement methods.

In the present work, we study the effect of photochemical and microbial transformations on isotopic signatures of riverine DOC. We measured the potential isotopic shifts of $\delta^{13} \mathrm{C}_{\mathrm{DOC}}$ during (1) abiotic photochemical mineralization of a portion of the $\mathrm{DOC}$ pool to $\mathrm{CO}_{2}$ and other purgeable organics and inorganics associated with a nearly complete photochemical decomposition of riverine chromophoric DOM $(\mathrm{CDOM})$ and (2) the bacterial mineralization of biologically labile DOC produced during the photochemical transformation of DOC. The riverine DOC was collected from 10 major rivers, cumulatively representing one-third of the world's freshwater discharge and $28 \%$ of the marine input of continental DOC (Cauwet, 2002), allowing us to appropriately constrain the continental end-member. We calculate the percentage of DOC that resists photochemical and microbial degradation and measure the $\delta^{13} \mathrm{C}_{\mathrm{DOC}}$ signature of DOC before and after the photochemical treatment and microbial degradation.

\section{Materials and methods}

\subsection{Riverine samples}

The rivers selected in this study are responsible for nearly one-third of both freshwater discharge and DOC flux to the ocean (Table 1). They drain $25 \%$ of the continental land area in a wide range of ecosystems and climates on five continents (Milliman and Farnsworth, 2011). The selected rivers provide a representative end-member of riverine DOC, which can be used as a predictive sample set for the behavior of riverine DOC in oceanic waters.

A water sample was collected from each river during the season of high discharge in $10 \mathrm{~L}$ polyethylene containers (cleaned with detergent, rinsed with acid and Milli-Q water). All samples were collected in one location upstream from the freshwater-saltwater transition zone. The samples were thus representative of the DOC discharged to the coastal ocean at the time of sampling. The Amazon River is the only exception: owing to sampling constraints, it was collected at two locations upstream of the confluence point of Rio Negro and Rio Solimoes. Samples from the two locations were mixed in an appropriate ratio (1:3, Rio Negro to Rio Solimoes) to represent the bulk Amazon River discharge.

The polyethylene containers were cleaned at the University of Helsinki and shipped to the local operators at each river (see list in Acknowledgments). The containers were filled in the center of the stream by direct immersion below the surface from a boat, except for the Mississippi and St. Lawrence rivers, where near-surface water (about $3 \mathrm{~m}$ below the surface) was collected with Niskin bottles and directly transferred to the polyethylene containers. All samples were immediately placed in a box to shield the water from sun and artificial light. They were left unfiltered/unkilled upon shipment and storage at the University of Helsinki (the time lag between sampling and measurement was between 80 and 390 days) so that the most labile fraction of the DOC (L-DOC) in all samples was decomposed prior to the measurement reported in this study (see below). The samples 
were not refrigerated during transportation (about one week in most cases), but they were stored at $4{ }^{\circ} \mathrm{C}$ in the dark upon arrival in Helsinki. The same water samples used here have been also examined for the concentration of dissolved black carbon and the contribution of iron to CDOM (Jaffé et al., 2013; Xiao et al., 2013). Additional samples from the St. Lawrence River were collected at the same time as the polyethylene container, filtered onboard (pre-combusted GF/F filters, $0.7 \mu \mathrm{m}$ nominal pore size), acidified with ultrapure $\mathrm{HCl}$ to a $\mathrm{pH}<2$, and stored in pre-combusted glass vials.

\subsection{Irradiation experiment followed by a bioassay}

All samples were sterile-filtered $(0.2 \mu \mathrm{m}$, Sartobran 300, Sartorius) and separated into two batches of duplicates: one duplicate set of irradiated samples for each river to be compared to a corresponding duplicate set of dark control samples. Irradiated samples were placed in clean and combusted $\left(>2 \mathrm{~h}, 450^{\circ} \mathrm{C}\right)$ UV-transparent $750 \mathrm{~mL}$ quartz vials fitted with ground glass stoppers. A headspace corresponding to $10 \%$ of the vial internal volume was filled with $\mathrm{O}_{2}$ gas, and replenished after 4 days of irradiation to support complete oxidation of the UV-sensitive DOM fraction (Vähätalo and Wetzel, 2008). The samples were placed horizontally $1 \mathrm{~cm}$ below the surface of water on a stainless steel grid in a flowthrough pool of tap water regulated to $24.5 \pm 1.0^{\circ} \mathrm{C}$. They were exposed for 10 days to simulated solar radiation adjusted to a power that mimics the global mean of a halfyear UV dose of solar radiation incident to the surface of the ocean. The simulated solar radiation was generated using a metal halide lamp (Thorn OQ 1000, UK) and fluorescent tubes (UVA-340, Q-Lab Corp., Canada), and measured with a Macam SR 991 spectroradiometer in air $2 \mathrm{~cm}$ above the quartz flasks. The spectral irradiance of the artificial light source comprised the photochemically active part of UV radiation present in natural sunlight but excluded any environmentally non-relevant short-wavelength UV radiation absent from solar radiation incident to the ocean (Fig. 1b) (Chu and Liu, 2009). Dark controls were treated in the same way (sterile-filtered, but kept at $21.6 \pm 2.1^{\circ} \mathrm{C}$ in the dark). We preserved samples with ultrapure $\mathrm{HCl}(\mathrm{pH}<2)$ for DOC concentration and $\delta^{13} \mathrm{C}$ measurements at the beginning and end of the irradiation.

In order to quantify the microbial mineralization of labile DOC produced during the abiotic photochemical transformation of riverine DOM, we introduced a microbial inoculum into the irradiated and the dark control samples. Each sample received $\mathrm{KH}_{2} \mathrm{PO}_{4}$ to the final concentration of $133 \mu \mathrm{g} \mathrm{PL}^{-1}$ and unfiltered water from its corresponding river $(1 \% \mathrm{vol} / \mathrm{vol})$ as a source of phosphorus nutrient and microbial inoculum, respectively. These bioassay flasks contained an air headspace and were incubated in the dark at $22.0 \pm 0.5^{\circ} \mathrm{C}$. After 28 days of incubation, the samples were
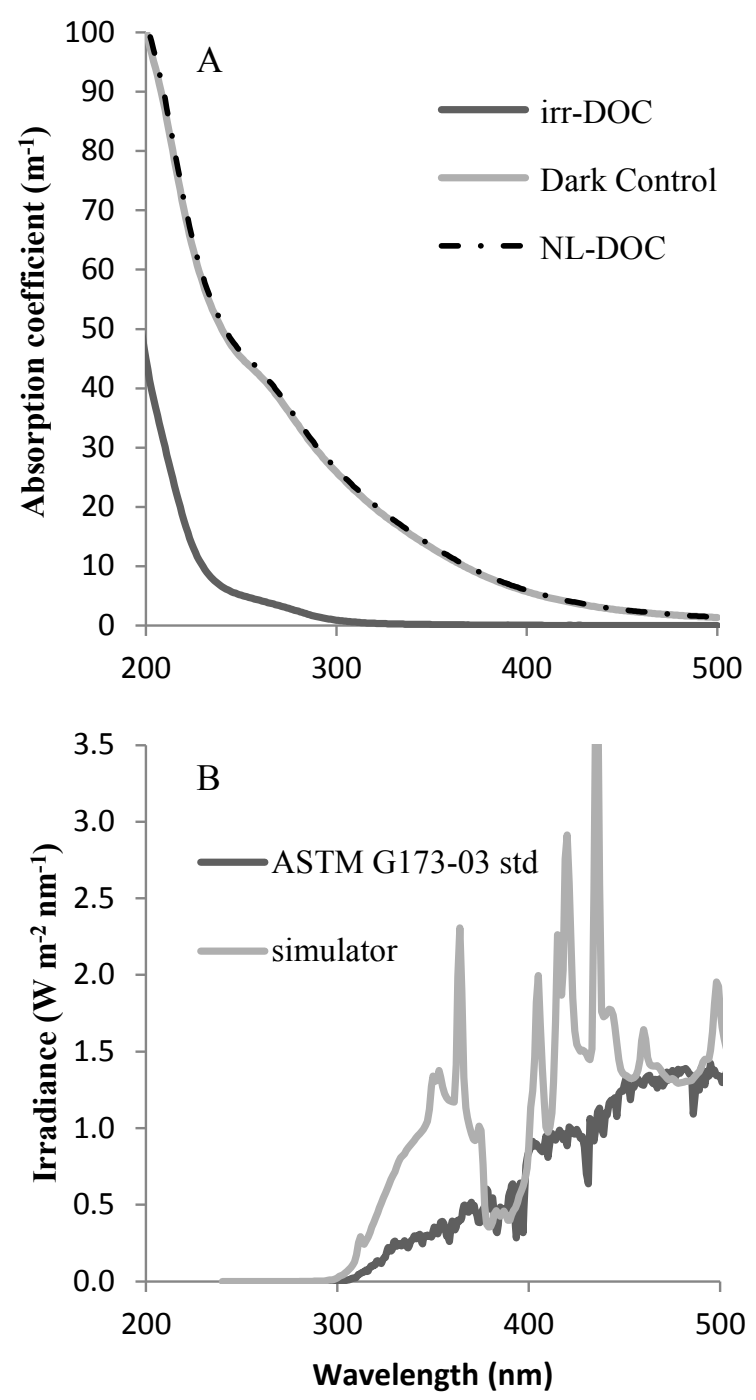

Figure 1. (A) Absorption coefficients of chromophoric dissolved organic matter in the initial NL-DOC, the irradiated DOC (irr-DOC) and the dark control of Amazon River, and (B) the spectral irradiance of solar simulator (simulator) and natural solar radiation (ASTM G173-03 std; Chu and Liu, 2009). Note that the absorption spectra for NL-DOC and the dark control are almost perfectly superimposed in (A).

filtered and preserved with $\mathrm{HCl}$ for the measurement of DOC concentration and its $\delta^{13} \mathrm{C}$ signature as explained above.

Note that the biologically labile organic compounds (LDOC) present in the original water samples were degraded during sample shipment and storage through microbial processes that have not been reported to affect ${ }^{13} \mathrm{C}$ signatures of DOM to a significant extent (Stutter et al., 2013; $\mathrm{Lu}$ et al., 2013). The DOC sample that was used at the start of the irradiation experiment therefore corresponds almost entirely to non-biologically labile DOC (NL-DOC). NL-DOC comprises semi-labile and refractory DOC, which have degradation rates on the order of years to centuries 
(Obernosterer and Benner, 2004). Note also that we report changes in the concentration and the $\delta^{13} \mathrm{C}$ signature of NLDOC $\left(\delta^{13} \mathrm{C}_{\mathrm{NL}-\mathrm{DOC}}\right)$ during a two-stage process: (1) the photobleaching of NL-DOC under sterile conditions, followed by (2) the biodegradation of the residual non-photosensitive organic compounds. Complete photobleaching causes the mineralization of the chromophoric DOC pool and/or its transformation to non-chromophoric DOC molecules. The DOC that is impervious to photooxidation is measured in the irradiated DOC sample (irr-DOC). The DOC that resists both the photobleaching and microbial degradation treatments because it is both transparent to UV radiation and biologically recalcitrant is defined as the recalcitrant DOC fraction (RDOC). R-DOC is therefore the residual DOC, measured directly after sequential treatments.

In natural systems, the degradation of NL-DOC by photooxidative and microbial pathways takes place simultaneously rather than consecutively. Our experimental design thus probably overestimates the relative importance of photochemical degradation since there is competition in natural environments for DOC substrates that are both bioavailable and photodegradable during daily light-dark cycles. However, as photobleaching leads to significant changes in $\delta^{13} \mathrm{C}$ signatures while the effect of biodegradation is much smaller and inconsistent (Table 1), we focused mostly on $\delta^{13} \mathrm{C}$-DOC shifts occurring during photobleaching when interpreting the fate NL-DOC in the ocean.

\subsection{High-temperature catalytic oxidation DOC-IRMS measurements}

A combustion total organic carbon (TOC) analyzer (OI Analytical model 1010, College Station, TX) was modified to reduce background contamination from atmospheric $\mathrm{CO}_{2}$ by replacing all gas-permeable polytetrafluoroethylene (PTFE) tubing with polyether ether ketone (PEEK) tubing. Ultrahigh-purity oxygen carrier gas and platinum-coated silica particles $(5 \% \mathrm{Pt}(w / w))$ were used for combustion of samples. Prior to analysis, the instrument furnace was kept at a temperature of $680^{\circ} \mathrm{C}$ under clean $\mathrm{O}_{2}$ for several hours, followed by the injection of a total of about 100 blanks, ensuring low and stable background $\mathrm{CO}_{2}$ levels. Blank $\mathrm{CO}_{2}$ was a small but non-negligible constituent of each $\mathrm{CO}_{2}$ sample peak, comprising both a system blank component and a water blank component $\left(\mathrm{CO}_{2}\right.$ released from the DOC analyzer combustion column upon injection of clean water). For each sequence, the overall magnitude and signature of the blank was determined using TOC-grade water (Sigma-Aldrich) and a number of calibration solutions. Blanks were always lower than $0.2 \mu \mathrm{g} \mathrm{mL}^{-1}$. Each sample was corrected for the contribution of the blank using the procedure outlined elsewhere (Panetta et al., 2008; Fry et al., 1992).

The TOC analyzer was interfaced to an Isoprime isotope ratio mass spectrometer (IRMS) through a Graden instrument chemical $\mathrm{CO}_{2}$ trap (GD-100), which allows quantita- tive recovery of $\mathrm{CO}_{2}$ while switching the carrier gas from ultrahigh-purity oxygen to ultrahigh-purity helium. Each sample injection therefore provided both the DOC concentration (by nondispersive infrared (NDIR) detection on the TOC analyzer and by the measured current on the TOC analyzer and by the measured current on the IRMS) and $\delta^{13} \mathrm{C}$ isotopic composition. The correlation coefficient between the NDIR and voltage-derived concentrations was $>0.98$. Dry certified sucrose standard $\left(\delta^{13} \mathrm{C}=-10.45 \pm 0.03 \%\right.$ ) from the International Atomic Energy Agency (IAEA-CH-6) and $\beta$-alanine (Sigma-Aldrich, $-26.18 \pm 0.33 \%$ o standardized in-house against several certified materials by elementalanalysis-IRMS) were dissolved in ultrapure water and used as calibration and reference compounds.

The injection volume was adjusted to $750 \mu \mathrm{L}$, generating enough $\mathrm{CO}_{2}$ for high-precision concentration and isotopic measurements without compromising combustion efficiency. Twin vials of each sample were run in either duplicate or triplicate, yielding standard deviations of $\leq 0.15 \mathrm{mg} \mathrm{L}^{-1}$ and $\leq 0.3 \%$ for concentration and isotopic measurements, respectively. Isotope data are reported with standard notation $\left(\delta^{13} \mathrm{C}\right)$ in parts per thousand $(\% \circ)$ relative to the Pee Dee Belemnite standard.

\section{Results}

\subsection{Riverine NL-DOC concentrations and $\delta^{13} \mathrm{C}_{\mathrm{NL}-\mathrm{DOC}}$ signatures}

The measured NL-DOC concentrations in the rivers examined ranged from $0.8 \pm 0.0 \mathrm{mg} \mathrm{L}^{-1}$ (Ganges-Brahmaputra) to $5.9 \pm 0.1 \mathrm{mg} \mathrm{L}^{-1}$ (Congo), with a yearly dischargeweighted average of $3.6 \pm 0.1 \mathrm{mg} \mathrm{L}^{-1}$ (Table 1) for all rivers. The $\delta^{13} \mathrm{C}_{\mathrm{NL}-\mathrm{DOC}}$ signatures ranged from $-29.0 \pm 0.2 \%$ o (Amazon) to $-26.0 \pm 0.2 \%$ (Mekong) with a yearly discharge-weighted average of $-28.1 \pm 0.2 \%$ (Table 1 ). These weighted average NL-DOC concentrations and $\delta^{13} \mathrm{C}_{\mathrm{NL}-\mathrm{DOC}}$ values could be used as a first-order estimate for terrestrial riverine DOC discharged in the ocean. Additional studies are, however, needed to improve the accuracy of this estimate by taking into account the quantitatively important rivers not sampled in this project, as well as potential seasonal and interannual variability in NL-DOC concentrations and $\delta^{13} \mathrm{C}_{\mathrm{NL}-\mathrm{DOC}}$ signatures.

The concentrations of NL-DOC and $\delta^{13} \mathrm{C}_{\mathrm{NL}-\mathrm{DOC}}$ signatures reported in Table 1 do not include the biologically labile fraction of DOC (L-DOC). L-DOC is rapidly consumed by microbes (hourly to daily timescales; in this study, LDOC was biodegraded during the shipping and storage of unkilled samples); therefore it is too reactive to contribute to the oceanic reservoir of DOC. L-DOC was not measured directly in samples other than the St. Lawrence River, where the L-DOC fraction accounted for $19 \pm 1 \%(n=3)$ of total DOC (measured on separate aliquots collected on the 
Table 1. The sampling locations of rivers, discharge rates, the concentration of non-labile DOC (NL-DOC) and its $\delta^{13} \mathrm{C}$ signature at the beginning of experiment, the loss of NL-DOC (\%) in 10-day-long irradiation (Photooxidation) and following 28-day bioassay (Microbial degradation) with associated $\delta^{13} \mathrm{C}$ signature in the residual DOC after the treatments. Literature DOC concentrations and $\delta^{13} \mathrm{C}$ signature are also given; sampling locations of literature values are not identical to sampling locations in this study. Standard deviations of duplicated $(n=3)$ determinations are given under the reported $\delta^{13} \mathrm{C}$ values in italics. The weighted averages were calculated by normalizing NL-DOC and $\delta^{13} \mathrm{C}$ with discharge rates. Details can be found in the indicated references: ${ }^{a}$ Cauwet (2002), ${ }^{\mathrm{b}}$ Mayorga et al. (2005), ${ }^{\mathrm{c}}$ Saliot et al. (2002), ${ }^{\mathrm{d}}$ Spencer et al. (2009), ${ }^{\mathrm{e}}$ Wang et al. (2004), and ${ }^{\mathrm{f}}$ Hélie and Hillaire-Marcel (2006).

\begin{tabular}{|c|c|c|c|c|c|c|c|c|c|c|c|}
\hline \multirow[t]{2}{*}{$\begin{array}{l}\text { River } \\
\text { name }\end{array}$} & \multirow[t]{2}{*}{ Latitude } & \multirow[t]{2}{*}{ Longitude } & \multirow{2}{*}{$\begin{array}{r}\text { Discharge } \\
\text { rate }^{\mathrm{a}} \\
\left(10^{12} \mathrm{~L} \mathrm{yr}^{-1}\right)\end{array}$} & \multicolumn{2}{|c|}{$\begin{array}{c}\mathrm{DOC}_{\text {total }} \\
\text { values literature } \\
\delta^{13} \mathrm{C}\end{array}$} & \multicolumn{2}{|c|}{$\begin{array}{l}\text { NL-DOC } \\
\delta^{13} \mathrm{C}_{\mathrm{NL}-\mathrm{DOC}}\end{array}$} & \multicolumn{2}{|c|}{$\begin{array}{l}\text { Photooxidation } \\
\delta^{13} \mathrm{C}_{\mathrm{irr}-\mathrm{DOC}}\end{array}$} & \multicolumn{2}{|c|}{$\begin{array}{l}\text { Microbial } \\
\text { degradation } \\
\delta^{13} \mathrm{C}_{\mathrm{R}-\mathrm{DOC}}\end{array}$} \\
\hline & & & & $\left(\mathrm{mg} \mathrm{L}^{-1}\right)$ & $(\% o)$ & $\left(\mathrm{mg} \mathrm{L}^{-1}\right)$ & $(\% o)$ & (\% loss) & $(\% o)$ & (\% loss) & $(\%)$ \\
\hline \multirow[t]{2}{*}{ Amazon } & $03^{\circ} 08^{\prime} 00^{\prime \prime} \mathrm{S}$ & $59^{\circ} 54^{\prime} 10^{\prime \prime} \mathrm{W}$ & 5780 & $3.3^{\mathrm{a}}$ & $-29.0^{\mathrm{b}}$ & 4.0 & -29.0 & 37.4 & -27.4 & 33.0 & -27.4 \\
\hline & & & & & 0.9 & -0.1 & -0.2 & -0.7 & 0.0 & -3.0 & -0.3 \\
\hline \multirow[t]{2}{*}{ Danube } & $45^{\circ} 13^{\prime} 38^{\prime \prime} \mathrm{N}$ & $28^{\circ} 44^{\prime} 05^{\prime \prime} \mathrm{E}$ & 198 & $2.6^{\mathrm{c}}$ & $-26.9^{\mathrm{c}}$ & 2.3 & -28.4 & 33.5 & -27.0 & 33.1 & n.a. \\
\hline & & & & & & 0.0 & -0.2 & -4.2 & -0.2 & -0.3 & \\
\hline \multirow[t]{2}{*}{ Yangtze } & $31^{\circ} 45^{\prime} 49^{\prime \prime} \mathrm{N}$ & $121^{\circ} 2^{\prime} 22^{\prime \prime} \mathrm{E}$ & 925 & $1.9^{\mathrm{a}}$ & n.a. & 1.7 & -27.6 & 34.5 & -27.1 & 28.7 & n.a. \\
\hline & & & & & & 0.0 & -0.4 & n.a. & n.a. & -0.6 & \\
\hline \multirow[t]{2}{*}{ Congo } & $04^{\circ} 18^{\prime} 18^{\prime \prime} \mathrm{S}$ & $15^{\circ} 28^{\prime} 32^{\prime \prime} \mathrm{E}$ & 1300 & $10.7^{\mathrm{d}}$ & $-29.2^{\mathrm{d}}$ & 5.9 & -27.1 & 43.4 & -25.4 & 37.7 & -26.2 \\
\hline & & & & & & -0.1 & -0.2 & -0.1 & -0.5 & n.a. & n.a. \\
\hline \multirow[t]{2}{*}{ Parana } & $34^{\circ} 18^{\prime} 07^{\prime \prime} \mathrm{S}$ & $58^{\circ} 32^{\prime} 47^{\prime \prime} \mathrm{W}$ & 470 & $12.6^{\mathrm{a}}$ & n.a. & 2.9 & -27.0 & 30.9 & -24.0 & 28.7 & -26.5 \\
\hline & & & & & & 0.0 & 0.0 & -2.1 & 0.0 & n.a. & n.a. \\
\hline \multirow[t]{2}{*}{ Lena } & $71^{\circ} 54^{\prime} 14^{\prime \prime} \mathrm{N}$ & $127^{\circ} 15^{\prime} 16^{\prime \prime} \mathrm{E}$ & 505 & $7.1^{\mathrm{a}}$ & n.a. & 5.4 & -26.9 & 29.6 & -25.4 & 25.0 & -25.5 \\
\hline & & & & & & -0.2 & -0.1 & -1.8 & -0.1 & 0.0 & 0.0 \\
\hline \multirow[t]{2}{*}{ Mississippi } & $29^{\circ} 02^{\prime} 20^{\prime \prime} \mathrm{N}$ & $89^{\circ} 19^{\prime} 20^{\prime \prime} \mathrm{W}$ & 410 & $4.2^{\mathrm{e}}$ & $-28.0^{\mathrm{e}}$ & 3.4 & -26.6 & 25.1 & -25.7 & 31.7 & n.a. \\
\hline & & & & & & -0.1 & -0.1 & -2.1 & -0.4 & -1.6 & \\
\hline \multirow{2}{*}{$\begin{array}{l}\text { Ganges- } \\
\text { Brahmaputra }\end{array}$} & $23^{\circ} 34^{\prime} 12^{\prime \prime} \mathrm{N}$ & $90^{\circ} 10^{\prime} 54^{\prime \prime} \mathrm{E}$ & 971 & $3.7^{\mathrm{a}}$ & n.a. & 0.8 & -26.5 & 34.0 & -25.8 & 21.9 & n.a. \\
\hline & & & & & & 0.0 & -0.9 & -4.4 & -0.4 & -2.1 & \\
\hline \multirow[t]{2}{*}{ St. Lawrence } & $46^{\circ} 54^{\prime} 45^{\prime \prime} \mathrm{N}$ & $70^{\circ} 52^{\prime} 32^{\prime \prime} \mathrm{W}$ & 413 & $3.9^{f}$ & $-26.4^{\mathrm{f}}$ & 3.6 & -26.1 & 16.0 & -25.5 & 31.9 & -25.2 \\
\hline & & & & & 0.6 & -0.1 & -0.2 & n.a. & n.a. & -0.8 & 0.0 \\
\hline \multirow[t]{2}{*}{ Mekong } & $11^{\circ} 33^{\prime} 28^{\prime \prime} \mathrm{N}$ & $104^{\circ} 56^{\prime} 53^{\prime \prime} \mathrm{E}$ & 666 & n.a. & n.a. & 1.4 & -26.0 & 16.6 & -24.5 & 25.1 & n.a. \\
\hline & & & & & & -0.1 & -0.2 & n.a. & n.a. & n.a. & \\
\hline Weighted & & & & & & 3.6 & -28.1 & 35.9 & -26.6 & 32.6 & -26.2 \\
\hline average & & & & & & -0.1 & -0.2 & -1.8 & -0.2 & -2.4 & -0.9 \\
\hline
\end{tabular}

sampling day), consistent with previously reported estimates of 13 and $28 \%$ in lacustrine and swamp settings (Obernosterer and Benner, 2004) or $22 \pm 12 \%$ of total DOC in the coastal ocean (Lønborg and Álvarez-Salgado, 2012).

The $\delta^{13} \mathrm{C}_{\mathrm{DOC}}$ signatures measured for St. Lawrence River total DOC (including L-DOC, $-26.4 \pm 0.4 \%$ ) and NL-DOC $(-26.1 \pm 0.2 \%$ o $)$ suggest that the removal of L-DOC by biodegradation does not alter $\delta^{13} \mathrm{C}_{\mathrm{DOC}}$ signatures, in agreement with several earlier studies (Stutter et al., 2013; Lu et al., 2013).

\subsection{Effect of irradiation and microbial incubation on NL-DOC concentration and $\delta^{13} \mathrm{C}$ signature}

Irradiation with artificial sunlight photochemically destroyed the chromophores that absorbed in the UV and blue regions of the spectrum, nearly completely extinguishing the DOC absorption at $>350 \mathrm{~nm}$ for all samples (Figs. 1 and 2). A fraction of the DOC in samples was converted to $\mathrm{CO}_{2}$ (or other small purgeable organic molecules) during the irradiation, as indicated by the lower irr-DOC concentration compared to NL-DOC. The loss of NL-DOC by photomineralization ranged from $16 \%$ (St. Lawrence) to $43 \%$ (Congo), with an average of $36 \%$ for the all rivers examined (Table 1 ), corroborating previously reported literature values (Obernosterer and Benner, 2004). No well-stained bacteria were found in the irradiated samples by epifluorescence microscopy, indicating that the partial mineralization of NL-DOC (to DIC), as well as any structural, spectral and isotopic modifications of the NL-DOC pool were incurred due to a purely abiotic photochemical process. In contrast to the irradiated samples, the light absorption by CDOM or the concentration of NLDOC did not change significantly in the dark control samples during the 10-day treatment (Figs. 2 and 3b).

In our study, irr-DOC was consistently enriched in ${ }^{13} \mathrm{C}$ relative to NL-DOC in all irradiated riverine samples by $0.5 \%$ (Yangtze) to $2.3 \%$ (Parana), indicating the mineralization of a pool of DOC that was depleted in ${ }^{13} \mathrm{C}$ relative to NL-DOC. The complete mineralization of photosensitive DOC therefore shifted the signature of the average riverine DOC by $1.5 \%$ (from -28.1 to $-26.6 \%$, Table 1 and Fig. 4). Dark control samples did not change during the course of the irradiation step as they were protected from the radiation and sterile-filtered. Consequently, no changes in the light absorption by CDOM or the concentration of DOC incurred in the 


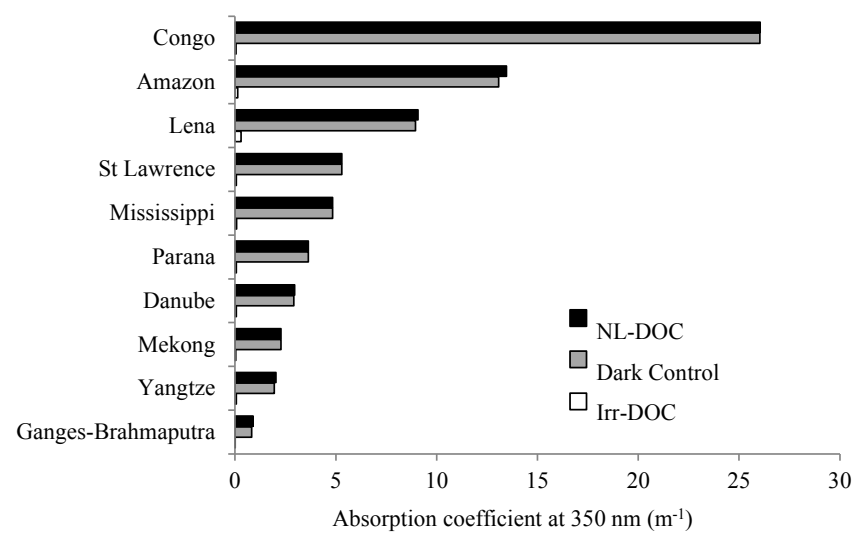

Figure 2. Absorption coefficient of chromophoric DOM at $350 \mathrm{~nm}$ in the samples before (initial NL-DOC, black) and after the irradiation experiment (irr-DOC, white) and the dark controls (grey).

dark control samples during the 10-day treatment (Fig. 2 and 3b).

UV radiation produced bioavailable, labile DOC that was consumed during the course of the incubation. This DOC pool represented between $21.9 \%$ (Ganges-Brahmaputra) and $37.7 \%$ (Congo) (average of $32.6 \pm 2.4 \%$ ) of the NLDOC pool (Fig. $3 \mathrm{~b}$ and Table 1). The corresponding microbial consumption in the dark control samples was negligible ( $5 \pm 7 \%$ of NL-DOC in all 10 rivers) as exemplified for the Amazon River in Fig. 3b, indicating the absence of biologically labile compounds within non-irradiated samples. After the completion of the irradiation/inoculation experiment, a residual, recalcitrant DOC fraction (R-DOC) remained. The R-DOC fraction ranged between $18.9 \%$ (Congo) and $58.3 \%$ (Mekong), with a weighted average of $31.5 \pm 1.5 \%$ (Fig. 5, Table 1).

The NL-DOC pool is therefore separable into three fractions, each comprising roughly one-third of the DOC: (1) a fraction that is directly mineralized to DIC (or degraded into small purgeable organics) during photobleaching, (2) a fraction of DOC that becomes labile as a result of UV-induced molecular transformations, and (3) a residual, recalcitrant fraction (R-DOC).

Riverine NL-DOC samples that were most depleted in ${ }^{13} \mathrm{C}$ contained the smallest R-DOC fraction (Fig. 5a). The Congo River was an exception to the $\delta^{13} \mathrm{C}$ trend (Fig. 5a), experiencing the highest NL-DOC losses of all rivers but displaying relatively enriched values. The fraction of R-DOC was also related to the amount of $\mathrm{CDOM}$, indicated by an absorption coefficient at $350 \mathrm{~nm}\left(\mathrm{aCDOM}_{350}\right)$ of NL-DOC (Fig. 5b).
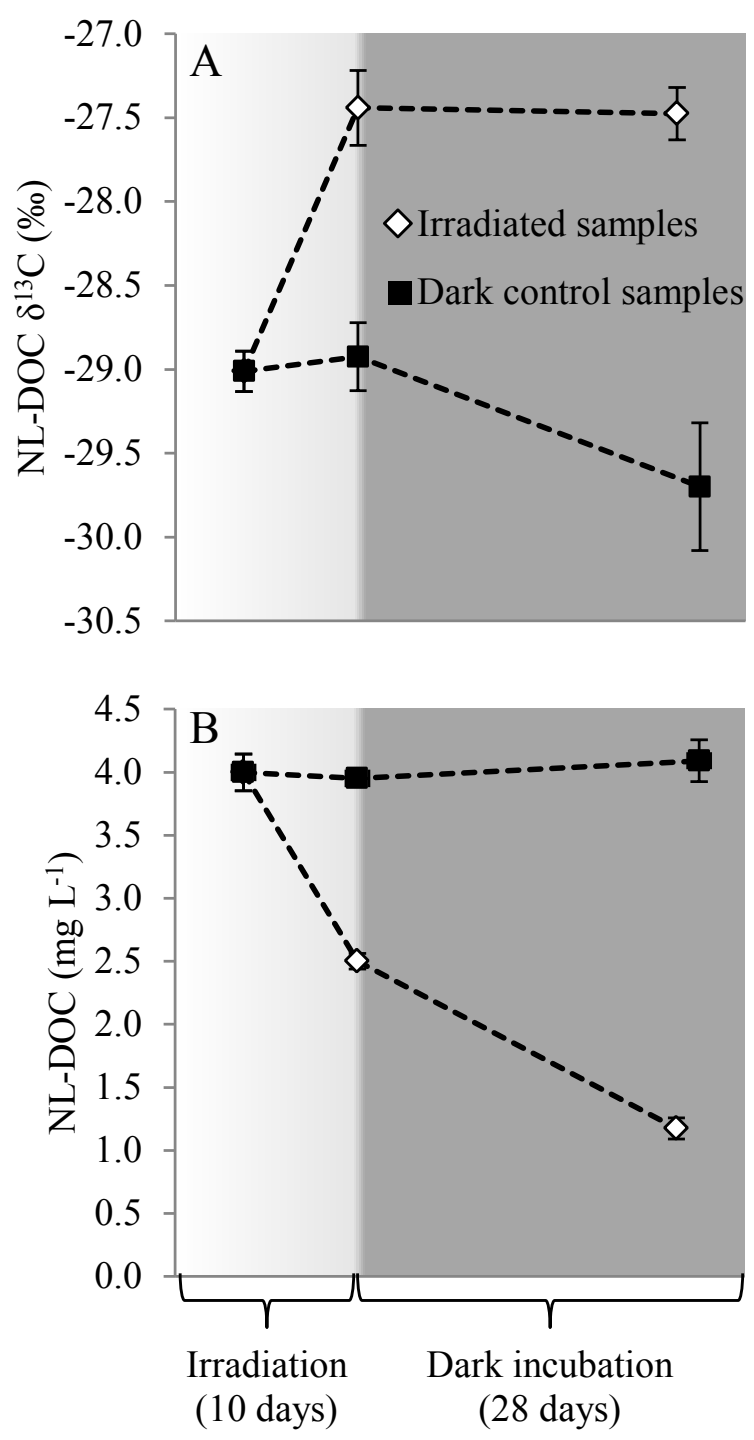

Figure 3. Concentration of NL-DOC and its $\delta^{13} \mathrm{C}$ value in a representative riverine sample (the Amazon River) during the 10-day abiotic photooxidation and the following 28-day microbial degradation initiated by inoculation with unfiltered riverine water containing indigenous bacteria. Irradiated samples are shown in white, while the dark controls are shown in black.

\section{Discussion}

\subsubsection{Photochemically induced shift in $\delta^{13} \mathrm{C}_{\mathrm{NL}-\mathrm{DOC}}$ signatures and optical parameters}

Our irradiation experiment was designed to achieve the complete UV-induced photochemical decomposition of riverine CDOM (Figs. 1 and 2). Photochemical destruction by simulated solar radiation most effectively targets chromophores that absorb in the regions of the spectrum that overlap with the most intense irradiance bands (Fig. 1A) and results in the virtually complete loss of DOC absorption at these 
wavelengths. We observed the nearly complete disappearance of the terrestrial optical signal (loss of DOM absorption at $350 \mathrm{~nm}\left(\mathrm{aCDOM}_{350}\right)$ ) for all riverine samples (Fig. 2), which has previously been demonstrated by other irradiation experiments and field studies measuring CDOM in situ or by remote sensing (Vodacek et al., 1995; Vähätalo and Wetzel, 2008; Nelson et al., 2010; Fichot and Benner, 2012). It is known that photochemical reactions specifically target certain molecular moieties/types, absorbing light in the blue and UV region of the spectrum (high $a_{\lambda<350 \mathrm{~nm}}$ ) (Mopper and Kieber, 2002). The chromophoric DOM component constitutes an important portion of the organic carbon in many lakes and rivers, and even some coastal waters, and is structurally similar to soil humics, with a characteristic brown color (Hedges and Oades, 1997; Blough and Del Vecchio, 2002). It is composed of a mixture of lignocellulose-derived polyelectrolytes that result mainly from the decay of terrestrial vegetation and aquatic detritus (Gonsior et al., 2008; Dittmar et al., 2007). The photobleaching of CDOM was concomitant to the photochemical mineralization of a portion of NL-DOC, as illustrated by a loss of DOC in the irradiated samples (irr-DOC) (Fig. 3b and Table 1). The photomineralization of the NL-DOC pool ranged from $16 \%$ (St. Lawrence) to $43 \%$ (Congo), with an average of $36 \%$ for the all rivers examined (Table 1).

A removal process, such as photooxidation, that targets specific types of molecules ultimately causes a change in the chemical composition of DOC in the irradiated samples. This change in the molecular makeup of DOC was reflected by an isotopic enrichment from $\delta^{13} \mathrm{C}_{\mathrm{NL}-\mathrm{DOC}}$ to $\delta^{13} \mathrm{C}_{\text {irr-DOC }}$ following photodegradation $(0.5 \%$ (Yangtze) to $2.3 \%$ (Parana), Table 1 and Fig. 4). The average riverine $\delta^{13} \mathrm{C}_{\mathrm{NL}-\mathrm{DOC}}$ shifted by $1.5 \%$ (from -28.1 to $-26.6 \%$; $\delta^{13} \mathrm{C}_{\mathrm{NL}-\mathrm{DOC}}$ and $\delta^{13} \mathrm{C}_{\mathrm{irr}-\mathrm{DOC}}$ are statistically different at a 99\% confidence interval, Table 1 and Fig. 4). Other studies have also highlighted similar shifts towards heavier $\delta^{13} \mathrm{C}$ DOC values upon photochemical mineralization of DOC. These shifts have averaged $6 \%$ for a plant leachate, $1.2 \%$ o for a humic lake, $0.7 \%$ for the Altamaha River, $1.6 \%$ for the Satilla River, and 3.1\%o for the Congo River (Osburn et al., 2001; Vähätalo and Wetzel, 2008; Spencer et al., 2009; Opsahl and Zepp, 2001; Lu et al., 2013). The photochemical isotopic shift measured in this study for the Congo River was not as pronounced as reported by Spencer et al. (2009) for the same river (1.7 vs. $3.1 \%$, respectively). This apparent disagreement may be related to differences in the temperature and the source of irradiation, but more likely to different initial $\delta^{13} \mathrm{C}$-DOC signatures in the two studies $(-27.1 \%$ in this study vs. $-29.2 \%$ or for Spencer et al., 2009); the $\delta^{13} \mathrm{C}$ signature of irr-DOC was similar in both studies $(-26.2$ vs. $-26.3 \%$ ). The $\delta^{13} \mathrm{C}$ signature of total DOC can vary by a few parts per thousand at least in headwaters catchments during storm events (Lambert et al., 2014) and at the mouth of Arctic rivers between rivers and/or seasons (Neff et al., 2006;



Figure 4. The isotopic signature $\left(\delta^{13} \mathrm{C}\right)$ in the initial NL-DOC, in the irradiated NL-DOC (Irr-DOC) and in the dark control NL-DOC (Dark Control). The error bars show standard deviations of measurements $(n=3)$.

Raymond et al., 2007), with more depleted signatures corresponding to recently synthesized fresh plant materials.

In our study, $\delta^{13} \mathrm{C}_{\text {irr-DOC }}$ of irradiated riverine samples was consistently enriched relative to $\delta^{13} \mathrm{C}_{\mathrm{NL}-\mathrm{DOC}}$ (Table 1 , Fig. 4). The enriched $\delta^{13} \mathrm{C}$ of UV-resistant irr-DOC relative to NL-DOC occurs due to the mineralization of ${ }^{13} \mathrm{C}$ depleted NL-DOC components, varying between -25.8 and $-33.9 \%$ and averaging $-30.8 \%$ (calculated by isotopic and mass balances of NL-DOC and irr-DOC from the 10 studied rivers). Naturally photosynthesized ${ }^{13} \mathrm{C}$-depleted components of terrestrial plants include, amongst others, macromolecular aromatic compounds such as lignin, tannins and cutins, which are depleted by 4-7\%o relative to the bulk plant material (Hayes, 2001; Goñi et al., 2005). It is possible that partial photooxidative breakdown can damage these compounds sufficiently to produce low-molecular-weight, oxygenated compounds that bear little or no resemblance to their parent molecules, but that closely match the small, molecularly uncharacterized molecules that make up the bulk of deep-ocean DOC (Benner et al., 1997). Photobleaching can therefore simultaneously explains the three main changes in DOC that make riverine DOC appear deceivingly more marine in nature: (1) the decrease in average molecular size (Dittmar et al., 2007; Opsahl and Benner, 1998; Hernes and Benner, 2003), (2) the reduction in the abundance of aromatic/unsaturated functionalities that absorb UV light (such as lignin; Vähätalo et al., 1999) and (3) the overall enrichment in $\delta^{13} \mathrm{C}$. 


\subsection{Does biodegradation shift the $\delta^{13} \mathrm{C}$ signature of terrestrial NL-DOC?}

Photochemical enhancement of DOM bioavailability has previously been shown to be an important factor in the alteration of estuarine and coastal heterotrophy (Zepp, 2005; Chin-Leo and Benner, 1992; Vähätalo et al., 2011). We therefore extended the irradiation experiment with a bioassay to assess microbial decomposition of irradiated DOC samples (irr-DOC). Microbes consumed photoproduced, labile DOC, comprising between $21.9 \%$ (Ganges-Brahmaputra) and $37.7 \%$ (Congo) (average of $32.6 \pm 2.4 \%$ ) of the initial NL-DOC sample (Fig. $3 \mathrm{~b}$ and Table 1), a DOC fraction that was similar in size to the directly photomineralized DOC (Table 1). Microbial consumption in the corresponding dark control samples was negligible ( $5 \pm 7 \%$ of NL-DOC in all 10 rivers, data not shown) as exemplified for the Amazon River in Fig. 3b. Our results are in agreement with earlier studies, which have found labile photoproducts to be quantitatively important components of DOC photooxidation (Vähätalo et al., 2003; Pullin et al., 2004; Obernosterer and Benner, 2004; Aarnos et al., 2012).

In the samples from the Amazon, Lena and St. Lawrence rivers, the isotopic shifts associated to the mineralization of labile photoproducts were smaller than the average standard deviation of $\delta^{13} \mathrm{C}_{\mathrm{DOC}}$ measurements $(\approx 0.3 \%$ ) (Table 1$)$. These negligible isotopic shifts are in agreement with the lack of shifts in the biodegradation L-DOC fraction of the St. Lawrence River sample and with data reported in earlier studies (Obernosterer and Benner, 2004; Stutter et al., 2013; Lu et al., 2013). The $\delta^{13} \mathrm{C}$ signature of other two samples, the Congo and the Parana rivers, decreased by 1.2 and $2.5 \%$, respectively (Table 1). Though more work is needed to better understand the reason for this ${ }^{13} \mathrm{C}$ depletion, it could be explained by the consumption of microbially labile photoproducts that are more enriched in ${ }^{13} \mathrm{C}$, possibly produced by the C4 carbon fixation pathway. Note, however, that this shift does not affect the main conclusions of this work as the $\delta^{13} \mathrm{C}$ signatures of the R-DOC fraction were still less depleted than the initial NL-DOC signatures.

\subsection{Relationship between NL-DOC photochemical susceptibility and $\delta^{13} \mathrm{C}_{\mathrm{NL}-\mathrm{DOC}}$}

The extent of photodegradation of riverine samples was evaluated by the concentration of the residual UV and microbially resistant component (R-DOC). R-DOC was inversely correlated to absorption of NL-DOC at $350 \mathrm{~nm}\left(\mathrm{aCDOM}_{350}\right)$ (Fig. 5b). As aromatic compounds such as lignin are the primary components of DOC that absorb light (Hernes and Benner, 2003), it is likely that samples with the lowest relative R-DOC contribution contain the freshest terrestrial NLDOC (less photobleached) collected in rivers with low residence time and/or efficient shielding from light (DOM selfshielding, high particulate loads and/or forested banks).

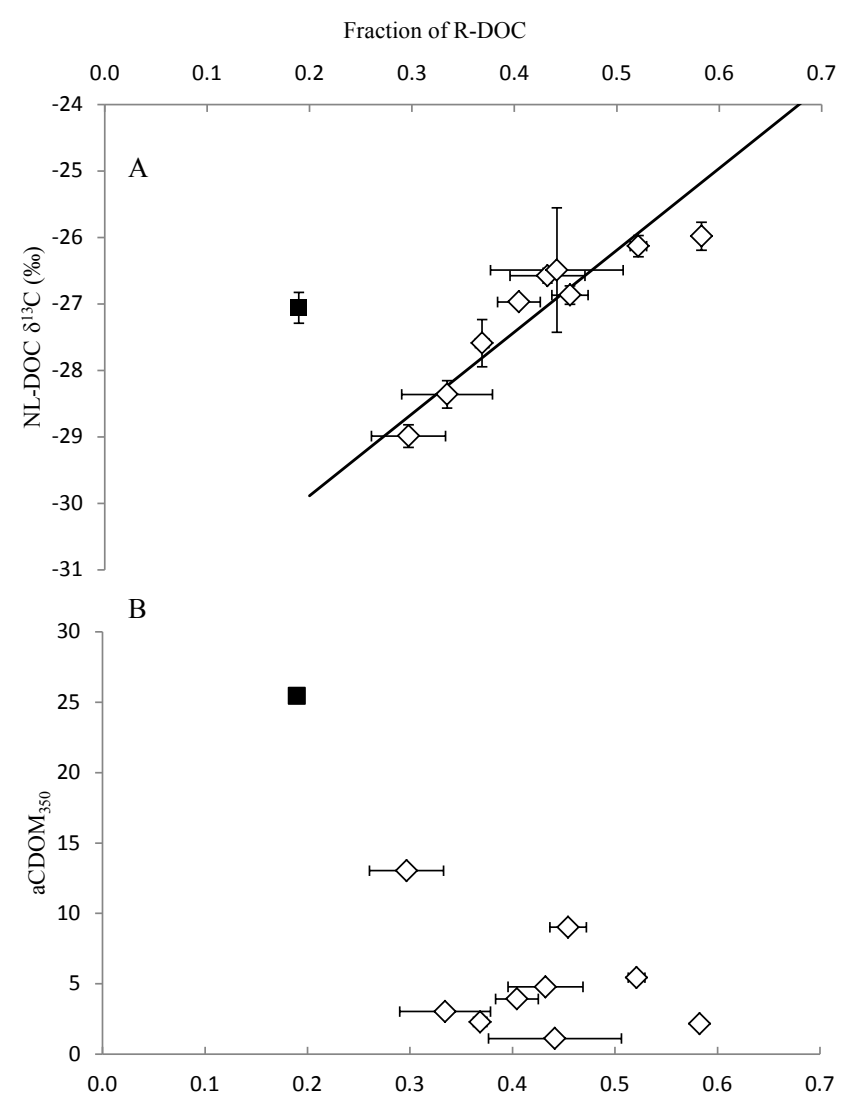

Figure 5. (A) Fraction of NL-DOC resistant to photooxidation followed by bacterial incubation (R-DOC) as a function of the $\delta^{13} \mathrm{C}$ signature of NL-DOC, and (B) the absorption coefficient at $350 \mathrm{~nm}$ for all riverine samples. The error bars in (A) represent the propagated uncertainty for the fraction of NL-DOC remaining following the two treatments. The trend line describes a model 2 linear regression including all data except the Congo River.

Riverine NL-DOC samples that were most depleted in ${ }^{13} \mathrm{C}$ had increased susceptibility towards direct abiotic photodegradation and photoproduction/biodegradation of labile DOC compounds (Fig. 5a). The initial $\delta^{13} \mathrm{C}_{\mathrm{NL}-\mathrm{DOC}}$ was most depleted (-29.0\%; Table 1, Fig. 5a) in the Amazon River sample, where the fraction of residual DOC (R-DOC) resisting photodegradation was low $(0.296$, Fig. 5a); abiotic photooxidation and the following microbial decomposition accounted for fractions of 0.374 and 0.330 , respectively (Table 1). The fraction of R-DOC was highest (0.583) in the river sample with the highest initial $\delta^{13} \mathrm{C}_{\mathrm{NL}-\mathrm{DOC}}$ (-26.0\% ; Mekong, Table 1, Fig. 5a). Plots of the fraction of R-DOC versus $\delta^{13} \mathrm{C}_{\mathrm{NL}-\mathrm{DOC}}$ for all rivers (the Congo River was treated as an outlier; see below) yielded a linear plot with a high correlation coefficient $(0.925)$ and a relatively low standard error on the slope $( \pm 1.69 \%)$ and $y$ intercept $( \pm 0.73 \%$ ). The model 2 linear regression shown in Fig. 5a (fraction R-DOC $\left.=\delta^{13} \mathrm{C}_{\mathrm{NL}-\mathrm{DOC}}+32.35\right) / 12.31$ ) could therefore potentially be used as predictive tool 
for estimating the maximum photochemical and bacterial removal of riverine NL-DOC in the ocean using the $\delta^{13} \mathrm{C}_{\mathrm{NL}-\mathrm{DOC}}$ of riverine samples.

We draw more information from the Fig. 5a correlation by operationally separating NL-DOC into two distinct DOC pools: mineralizable DOC (either through abiotic photooxidation or bacterial decomposition) and recalcitrant DOC (RDOC). Each riverine sample has a different fractional contribution of these two DOC pools, depending on light exposure history, residence time and organic carbon source. With no contribution from R-DOC, NL-DOC is the most ${ }^{13} \mathrm{C}$-depleted $\left(\delta^{13} \mathrm{C}_{\mathrm{NL}-\mathrm{DOC}}=-32.4 \pm 0.7 \% o\right)$. This signature corresponds to purely photodegradable/biodegradable compounds, which explains its closeness to the calculated $\delta^{13} \mathrm{C}$ signature of the DIC lost during abiotic mineralization (average $\delta^{13} \mathrm{C}_{\mathrm{DIC}}=-30.8 \%$ ). The higher limit of $\delta^{13} \mathrm{C}_{\mathrm{NL}-\mathrm{DOC}}$ refers to the theoretical signature of purely recalcitrant DOC $(-20.0 \pm 0.4 \%$ ), which is interestingly similar to the signature of purely marine DOC $(\approx-20 \%$; see below; Bauer, 2002).

The Congo River was an outlier to the $\delta^{13} \mathrm{C}$ trend (dark square in Fig. 5a), experiencing the highest NL-DOC losses of all rivers but displaying relatively enriched values. This outlier could result from a relatively high discharge of $\mathrm{C} 4$ vascular plant material compared to the other rivers (these plant materials have more enriched $\delta^{13} \mathrm{C}$ values but have similar optical properties and molecular compositions to those of C3 vascular plants (Goñi et al., 1997), imparting them with similar propensities toward photodegradation). In one of the main tributaries of the Congo River, the $\delta^{13} \mathrm{C}$ signature of total DOC varies greatly between seasons $(-30.6$ to $-25.8 \%$ ) depending on hydrological cycle and multiple sources of DOC with contrasting $\delta^{13} \mathrm{C}$ signatures, including C4 plants (Bouillon et al., 2012). The relationship of Fig. 5a might not apply to rivers carrying a high load of $\mathrm{C} 4$ plantderived materials.

\subsection{The effect of photochemical $\delta^{13} \mathrm{C}$-shift when calculating the contribution of terrestrial NL-DOC to the oceanic DOC reservoir}

The results of the present study show that the R-DOC pool is variable, always large and in some cases the dominant pool of riverine DOC. There was a 3-fold difference in the contribution of R-DOC amongst rivers, ranging from $18.9 \%$ (Congo) to $58.3 \%$ (Mekong) of the NL-DOC pool, with a weighted average of $31.5 \pm 1.5 \%$ (Table 1, Fig. 5). Though terrestrial in nature, R-DOC is nearly transparent to UV radiation (Fig. 2) owing to the removal of chromophoric DOC. Our irradiation and incubation experiment therefore predicts that nearly one-third of the global riverine export of terrestrial DOC is undistinguishable from the genuine marine DOC pool using the currently used optical and molecularlevel methods, which both target the same aromatic, lightabsorbing moieties derived from lignin-like compounds. As
R-DOC is the fraction that is most likely to resist degradation in oceanic waters (slower turnover than the total riverine DOC pool), relying on these tracers to track terrestrial DOC within coastal systems and in the ocean likely greatly underestimated the terrestrial component, especially for waters that are extensively exposed to sunlight.

The highest exposure of DOM to sunlight occurs at the mouth of estuaries and river plumes, where fresh riverine waters are spread into a thin surface layer or are mixed into denser, more translucent saline waters. The exact half-life of riverine CDOM, however, depends on the depth of the photolytic zone (transparency related to particulate load and DOM shielding), as well as the time of exposure and the intensity of sunlight. Previous studies report CDOM halflives at approximately $1.5 \mathrm{yr}$ in irradiated seawater (Miller and Zepp, 1995) or 1000 to $4200 \mathrm{yr}$ in the mixed world ocean (Mopper et al., 1991). Based on these values, the non-refractory component of terrestrial DOC is not expected to be immediately photodegraded after its discharge into coastal/estuarine waters, but likely succumbs to UV-light or microbial decay during the course of the turnover of the oceanic DOC pool; this is consistent with the nearly complete absence of terrestrial chromophoric/lignin-containing molecules in the mid-ocean and deep bottom waters (Hernes and Benner, 2002; Blough and Del Vecchio, 2002; Hernes and Benner, 2006).

We extrapolate the mass of the recalcitrant R-DOC discharged into the global ocean using the size of R-DOC (as a fraction of NL-DOC) measured in our 10 large rivers. Firstly, the global riverine NL-DOC export ranges from 0.18 to $0.22 \times 10^{15} \mathrm{~g} \mathrm{C} \mathrm{yr}^{-1}$, assuming that NL-DOC is 72 to $87 \%$ (Obernosterer and Benner, 2004) of the total global riverine DOC export of $0.25 \times 10^{15} \mathrm{~g} \mathrm{C} \mathrm{yr}^{-1}$ (Cauwet, 2002). The theoretical maximal degradation of NL-DOC resulting from the combination of photobleaching and microbial degradation leaves behind the residual R-DOC fraction of 19 to $52 \%$ of NL-DOC; therefore we predict that the riverine R-DOC export ranges between 0.034 and $0.128 \times 10^{15} \mathrm{~g} \mathrm{C} \mathrm{yr}^{-1}$. Though it represents only a fraction of the total riverine DOC export, this yearly contribution of UV-resistant material equates to more than half the estimated turnover of DOC in the ocean $\left(0.1 \times 10^{15} \mathrm{~g} \mathrm{C} \mathrm{yr}^{-1}\right)$ (Williams and Druffel, 1987). The degradation, alteration and potential survival of portions of the R-DOC pool within the oceanic DOC pool should therefore be addressed.

Photochemical degradation shifts $\delta^{13} \mathrm{C}_{\mathrm{DOC}}$ signatures toward marine values, thus leading to underestimations of the terrestrial component and complicating the use of $\delta^{13} \mathrm{C}$-DOC for tracking terrigenous DOC in the ocean. The problem is exacerbated by the fact that the $\delta^{13} \mathrm{C}$ signatures of both the marine and terrestrial DOC components of oceanic waters are not well constrained (Bauer, 2002). These factors combined preclude the use of a two-end-member isotopic mixing model, as shown in Eq. (1), to directly calculate the fraction $(f)$ of terrestrial DOC in mid-ocean and deep-ocean water 
samples.

$\partial{ }^{13} \mathrm{C}_{\text {measured }}=f_{\text {marine }} \partial{ }^{13} \mathrm{C}_{\text {marine }}+f_{\text {riverine }} \partial{ }^{13} \mathrm{C}_{\text {riverine }}$

The marine DOC end-member is difficult to measure directly, but can be inferred from the predominant $\mathrm{C} 3$ fixation pathway in phytoplankton with a theoretical $19 \%$ fractionation from dissolved DIC in the ocean at temperatures of about $20^{\circ} \mathrm{C}$ (Bauer, 2002; Yu et al., 2008). A representative signature of $-20 \%$ has been used to track organic matter sources in coastal systems (Bauer, 2002); however the application of a $\delta^{13} \mathrm{C}$ signature that is representative of the global marine DOC pool is confounded by factors such as local ocean temperatures and phytoplankton species that influence this value $\left(\delta^{13} \mathrm{C}_{\text {marine }}\right.$ ranges from -17.5 to $25 \%$; most values are between -18 and $-22 \%$ ) (Fontugne and Duplessy, 1981). Constraining the stable isotopic signature of the riverine endmember is also difficult and requires that natural variability (Neff et al., 2006; Raymond et al., 2007; Bouillon et al., 2012) and processes that potentially shift the $\delta^{13} \mathrm{C}$ values be adequately considered.

The importance of photobleaching (both direct photobleaching and bacterial mineralization caused by a photochemically induced increase in bioavailability) as a sink for terrestrial DOC in the ocean is being increasingly recognized. Appropriately constraining the $\delta^{13} \mathrm{C}$ signature of the terrestrial DOC component that mixes with oceanic DOC is therefore required to account for the isotopic shifts occurring during the photochemical/microbial removal of a large fraction of the riverine DOC pool. Instead of using wellconstrained $\delta^{13} \mathrm{C}$ values for the marine and terrestrial endmembers ( $\delta^{13} \mathrm{C}_{\text {marine }}$ and $\delta^{13} \mathrm{C}_{\text {riverine, }}$, respectively) to calculate the absolute fraction of terrigenous DOC in a sample, we used a simple model to illustrate the effect of photobleaching of riverine DOC on the calculated proportion of terrigenous DOC. We ran our model using three realistic $\delta^{13} \mathrm{C}_{\text {marine values }}(-18,-20$ and $-22 \%$ ) and a range of total DOC $\delta^{13} \mathrm{C}$ values that are representative of the majority of the signatures measured for total DOC $\left(\delta^{13} \mathrm{C}_{\text {measured }}\right.$, $x$ axis in Fig. 6). A greater proportion of terrestrial DOC in a measured sample is calculated when using the $\delta^{13} \mathrm{C}$ of (1) the irr-DOC fraction, on average $1.5 \%$ more enriched than the unaltered riverine NL-DOM $\left(\delta^{13} \mathrm{C}_{\mathrm{irr}-\mathrm{DOC}}=-26.6 \%\right.$ ), instead of (2) the average unaltered riverine water (weighted using NL-DOC concentrations and riverine discharge rates, $\delta^{13} \mathrm{C}_{\mathrm{NL}-\mathrm{DOC}}=-28.1 \%$ ). Figure 6 shows a plot of the percent increase in the calculated proportion of the terrestrial component ( $y$ axis) in a measured sample when the photobleached riverine end-member is used instead of the unaltered riverine end-member. With representative $\delta^{13} \mathrm{C}_{\text {measured }}$ values that vary between -20 and $-26 \%$ and the three realistic $\delta^{13} \mathrm{C}_{\text {marine values, we obtain relative increases in }}$ contributions ranging between 0 and $22 \%$ using the new,

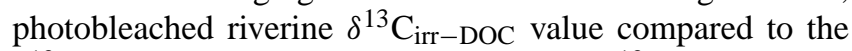
$\delta^{13} \mathrm{C}$ signature of unaltered riverine water $\left(\delta^{13} \mathrm{C}_{\mathrm{NL}-\mathrm{DOC}}\right)$. Increases in the percentage of terrigenous contribution were

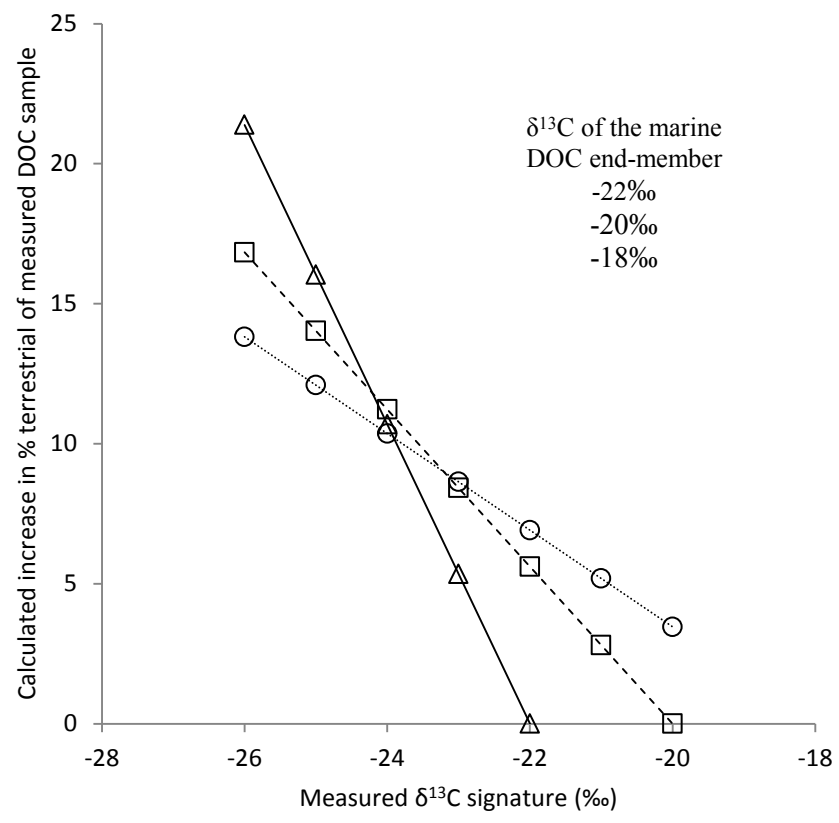

Figure 6. Percent increase in the contribution of terrestrial DOC $\left(100 \times\right.$ fraction terrestrial from Eq. 1) when the $\delta^{13} \mathrm{C}$ of photooxidized riverine water $\left(-26.6 \%\right.$ ) is used instead of the $\delta^{13} \mathrm{C}$ of unaltered riverine water $(-28.1 \%$ ) in a simple two-end-member mixing model over a range of measured $\delta^{13} \mathrm{C}$ signatures. Three theoretical $\delta^{13} \mathrm{C}$ values for the marine DOC end-member $\left(\delta^{13} \mathrm{C}=-18,-20\right.$ or $-22 \%$ ) were used to cover the vast majority of possible signatures for phytoplankton-derived DOC in the world ocean (Bauer, 2002; Yu et al., 2008).

most important when the signatures of the marine and terrestrial end-members were most alike. It is of note, however, that these calculations represent maximum values as they are based on the complete photobleaching of the CDOM fraction.

\section{Conclusions}

Only a small fraction of each river's NL-DOC discharge would have to be incorporated into the oceanic DOC pool to account for a non-negligible terrestrial contribution (as an example, assuming that the turnover time of the terrestrial oceanic component of oceanic DOC is similar to that of total oceanic DOC, the incorporation of $5 \%$ of the NLDOC discharge would correspond to a $10 \%$ terrestrial contribution). The scarceness of lignin and the $\delta^{13} \mathrm{C}$ range measured for marine DOM have, however, previously precluded a terrestrial DOC component of any significance in the open ocean (Williams and Druffel, 1987), though it is possible that the breadth and extent of chemical reactions that alter riverine DOC also affect our ability to molecularly and optically characterize the overall composition of DOM and to identify specific terrestrial proxies in photobleached DOM. We predict that up to two-thirds of the original NL-DOC 
pool can potentially be mineralized in the sunlit waters of ocean margins and mid-ocean regions, while the remaining one-third of the riverine pool is either undetected in oceanic waters or is in some other way degraded during its travel in oceanic waters. This work is instrumental in constraining photochemically induced shifts in $\delta^{13} \mathrm{C}_{\mathrm{NL}-\mathrm{DOC}}$ signatures, providing geochemists with critical information for determining the source and reactivity of different components of oceanic DOM. Accounting for $\delta^{13} \mathrm{C}$ shifts also allows for more efficient tracking of the transfer of organic matter from land to sea, which is a key link in the global carbon cycle, providing the most important pathway for ultimate preservation of terrigenous production (Hedges, 1992).

The natural variability in the $\delta^{13} \mathrm{C}$ signatures of the terrestrial and marine end-members precludes the application of a simple two-end-member isotopic mixing model to calculate the proportion of terrestrial DOC in the world ocean. However, such a model could be exploited on regional scales, in areas where the $\delta^{13} \mathrm{C}$ signatures of the end-members are well constrained in time and space. Along with new proxies (Hopmans et al., 2004), methods (Minor et al., 2012) and computer simulations (Belicka and Harvey, 2009) designed to track terrestrial DOM in the oceans, our results contribute to the ongoing effort to further elucidate the addition and removal processes of DOM during the turnover of oceanic waters. More specifically, new approaches are needed to detect and quantify the photobleached terrestrial compounds that fall outside of the analytical window of optical and molecular-level methods, which account for a large and variable proportion of terrestrial DOC (18 to $58 \%$ of the NL-DOC fraction for the 10 major rivers studied in this work).

Acknowledgements. The authors would like to thank all the scientists who contributed to sampling for the Big River project: E. M. Paolucci (Parana), D. E. Musibono (Congo), A. Shantz (Mekong), S. R. Khan (Ganges-Brahmaputra), Q. Huang (Yangtze), W. Schneider (Lena), A. Rivas and C. E. Rezende (Amazon), E. Petrescu (Danube), and H. E. Reader (Mississippi) for organizing the collection of water samples. We thank Paul Middlestead, Dan Duru and Graham Hughes for their instrument expertise, Ville Kasurinen for epifluorescence microscopy and Hanna Aarnos for her help in conducting the experiments. We also thank P. Albéric, R. Benner and an anonymous reviewer for their constructive comments on an earlier version of the manuscript. This work was supported by grants (for Y. Gélinas and A. V. Vähätalo) and scholarships (for K. Lalonde) from NSERC, CFI, FQRNT and the Academy of Finland.

Edited by: S. Bouillon

\section{References}

Aarnos, H., Ylöstalo, P., and Vähätalo, A. V.: Seasonal phototransformation of dissolved organic matter to ammonium, dissolved inorganic carbon, and labile substrates supporting biomass across the Baltic Sea, J. Geophys. Res., 117, G01004, doi:10.1029/2010JG001633, 2012.

Belicka, L. L. and Harvey, H. R.: The sequestration of terrestrial organic carbon in Artic Ocean sediments: A comparison of methods and implications for regional carbon budgets, Geochim. Cosmochim. Ac., 73, 6231-6248, 2009.

Benner, R., Biddanda, B., Black, B., and McCarthy, M.: Abundance, size distribution, and stable carbon and nitrogen isotopic compositions of marine organic matter isolated by tangential-flow ultrafiltration, Mar. Chem., 57, 243-264, 1997.

Blough, N. V. and Del Vecchio, R.: Chromophoric DOM in the coastal environment, in: Biogeochemistry of Marine Dissolved Organic Matter, edited by: Hansell, D. A. and Canfield, D. E., Elsevier, San Diego, 509-540, 2002.

Bouillon, S., Yambélé, A., Spencer, R. G. M., Gillikin, D. P., Hernes, P. J., Six, J., Merckx, R., and Borges, A. V.: Organic matter sources, fluxes and greenhouse gas exchange in the Oubangui River (Congo River basin), Biogeosciences, 9, 2045-2062, doi:10.5194/bg-9-2045-2012, 2012.

Cauwet, G.: DOM in the coastal zone, in: Biogeochemistry of Marine Dossolved Organic Matter, edited by: Hansell, D. A. and Carlson, C. A., Elsevier, San Diego, 579-602, 2002.

Chin-Leo, G. and Benner, R.: Enhanced bacterioplacton production and respiration at intermediate salinities in the Mississippi River plume, Mar. Ecol.-Prog. Ser., 87, 87-103, 1992.

Chu, S. X. and Liu, L. H.: Analysis of terrestrial solar radiation energy, Sol. Energy, 83, 1390-1404, 2009.

Dittmar, T., Whitehead, K., Minor, E. C., and Koch, B. P.: Tracing terrigenous dissolved organic matter and its photochemical decay in the ocean by using liquid chromatography/mass spectrometry, Mar. Chem., 107, 378-387, 2007.

Druffel, E. R. M., Williams, P. M., Bauer, J. E., and Ertel, J. R.: Cycling of dissolved and particulate organic matter in the open ocean, J. Geophys. Res., 97, 15639-15659, 1992.

Fichot, C. G. and Benner, R.: The spectral slope coefficient of chromophoric dissolved organic matter $\left(S_{275}-295\right)$ as a tracer of terrestrial dissolved organic carbon in river-influenced ocean margins, Limnol. Oceanogr., 57, 1453-1466, 2012.

Fontugne, M. R. and Duplessy, J. C.: Organic carbon isotopic fractionation be marine plankton in the temperature range -1 to $30{ }^{\circ} \mathrm{C}$, Oceanol. Acta, 4, 85-90, 1981.

Fry, B., Brand, W., Mersch, F. J., Tholke, K., and Garritt, R.: Automated analysis system for coupled $\delta^{15} \mathrm{~N}$ measurements, Anal. Chem., 64, 288-291, 1992.

Goñi, M. A., Ruttenberg, K. C., and Eglinton, T. I.: Sources and contribution of terrigenous organic carbon to surface sediments in the Gulf of Mexico, Nature, 389, 275-278, 1997.

Goñi, M. A., Yunker, M. B., Macdonald, R. W., and Eglinton, T. I.: The supply and preservation of ancient and modern components of organic carbon in the Canadian Beaufort Shelf of the Arctic Ocean, Mar. Chem., 93, 53-73, 2005.

Gonsior, M., Peake, B. M., Cooper, W. T., D’Andrilli, J., and Cooper, W. J.: Photochemically induced changed in dissolved organic matter identified by ultrahigh resolution fourier trans- 
form iron cyclontron resonance mass spectrometry, Environ. Sci. Technol., 43, 698-703, 2008.

Hansell, D. A., Carlson, C. A., Repeta, D. J., and Schlitzer, R.: Dissolved organic matter in the ocean: New insights stimulated by a controversy, Oceanography, 22, 52-61, 2009.

Hayes, J. M.: Fractionation of carbon and hydrogen isotopes in biosynthetis processes, Rev. Mineral. Geochem., 43, 225-277, 2001.

Hedges, J. I.: Global biogeochemical cycles: progress and problems, Marine Chemistry, 39, 67-93, 1992.

Hedges, J. I. and Oades, J. M.: Comparative organic geochemistries of soils and marine sediments, Org. Geochem., 27, 319-361, 1997.

Hélie, J.-F. and Hillaire-Marcel, C.: Sources of particulate and dissolved organic carbon in the St Lawrence River: isotopic approach, Hydrol. Process., 20, 1945-1959, 2006.

Helms, J. R., Stubbins, A., Ritchie, J. D., Minor, E. C., Kieber, D. J., and Mopper, K.: Absorption spectral slopes ratios as indicators of molecular weight, source and photobleaching of chromophoric dissolved organic matter, Limnol. Oceanogr., 53, 955-969, 2008.

Hernes, P. J. and Benner, R.: Transport and diagenesis of dissolved and particulate terrigenous organic matter in the North Pacific Ocean, Deep-Sea Res. Pt. I, 49, 2119-2132, 2002.

Hernes, P. J. and Benner, R.: Photochemical and microbial degradation of dissolved lignin phenols: Implications for the fate of terrigenous dissolved organic matter in marine environments, J. Geophys. Res., 108, 3291-3299, 2003.

Hernes, P. J. and Benner, R.: Terrigenous organic matter sources and reactivity in the North Atlantic Ocean and a comparion to the Arctic and Pacific oceans, Mar. Chem., 100, 66-79, 2006.

Hopmans, E. C., Weijers, J. W. H., Schefuß, E., Herfort, L., Sinninghe Damsté, J. S., and Schouten, S.: A novel proxy for terrestrial organic matter in sediments based on branched and isoprenoid tetraether lipids, Earth Planet. Sci. Lett., 224, 107-116, 2004.

Jaffé, P. R., Ding, Y., Niggemann, J., Vähätalo, A. V., Stubbins, A., Spencer, R. G. M., Campbell, J., and Dittmar, T.: Global charcoal mobilization from soils via dissolution and rivering transport to the oceans, Science, 340, 345-347, 2013.

Lambert, T., Pierson-Wickmann, A.-C., Gruau, G., Jaffrezic, A., Petitjean, P., Thibault, J. N., and Jeanneau, L.: DOC sources and DOC transport pathways in a small headwater catchment as revealed by carbon isotope fluctuation during storm events, Biogeosciences, 11, 3043-3056, doi:10.5194/bg-11-3043-2014, 2014.

Lønborg, C. and Álvarez-Salgado, X. A.: Recycling versus export of bioavailable dissolved organic matter in the coastal ocean and efficiency of the continental shelf pump, Global Biogeochem. Cy., 26, GB3018, doi:10.1029/2012GB004353, 2012.

Lu, Y., Bauer, J. E., Canuel, E. A., Yamashita, Y., Chambers, R. M., and Jaffé, P. R.: Photochemical and microbial alteration of dissolved organic matter in temperate headwater streams associated with different land use, J. Geophys. Res., 188, 566-580, 2013.

Maher, D. and Eyre, B. D.: Insights into estuarine benthic dissolved organic carbon (DOC) dynamics using ${ }^{13} \mathrm{C}$-DOC values, phospholipid fatty acids and dissolved organic nutrient fluxes, Geochim. Cosmochim. Ac., 75, 1889-1902, 2011.

Mayorga, E., Aufdenkampe, A. K., Masiello, C. A., Krusche, A. V., Hedges, J. I., Quay, P. D., Richey, J. E., and Brown, T. A.:
Young organic matter as a source of carbon dioxide outgassing from Amazonian river, Nature, 436, 538-541, 2005.

Meyers-Schulte, K. J. and Hedges, J. I.: Molecular evidence for a terrestrial component of organic matter dissolved in ocean water, Nature, 321, 61-63, 1986.

Miller, W. L. and Zepp, R. G.: Photochemical production of dissolved inorganic carbon from terrestrial organic matter: Significance to the oceanic organic carbon cycle, Geophys. Res. Lett., 22, 417-420, 1995.

Milliman, J. D. and Farnsworth, K. L.: River discharge to the coastal ocean - a global synthesis, 1 Ed., Cambridge University Press, 2011.

Minor, E. C., Steinbring, C. J., Longnecker, K., and Kujawinski, E. B.: Characterization of dissolved organic matter in Lake Superior and its watershed using ultrahigh resolution mass spectrometry, Org. Geochem., 43, 1-11, 2012.

Mopper, K. and Kieber, D. J.: Photochemistry and the cycling of carbon, sulfur, nitrogen and phosphorous, in: Biogeochemistry of Marine Dissolved Organic Matter, edited by: Hansell, D. A., and Canfield, D. E., Elsevier, San Diego, 456-503, 2002.

Mopper, K., Zhou, X., Kieber, D. J., Sikorski, R. J., and Jones, R. N.: Photochemical degradation of dissolved organic carbon and its impact on oceanic carbon cycle, Nature, 353, 60-62, 1991.

Moran, M. A., Sheldon Jr., W. M., and Zepp, R. G.: Carbon loss and optical property changes during long-term photochemical and biological degradation of estuarine dissolved organic matter, Limnol. Oceanogr., 45, 1254-1264, 2000.

Neff, J. C., Finlay, J. C., Zimov, S. A., Dadydov, S. P., Carrasco, J. J., Schuur, E. A. G., and Dadydova, A. I.: Seasonal changes in the age and structure of dissolved organic carbon in Siberian rivers and streams, Geophys. Res. Lett., 33, L23401, doi:10.1029/2006GL028222, 2006.

Nelson, N. B., Siegel, D. A., Carlson, C. A., and Swan, S. M.: Tracing global biogeochemical cycles and merional overturning circulation using chromophoric dissolved organic matter, Geophys. Res. Lett., 37, L03610, doi:10.1029/2009GL042325, 2010.

Obernosterer, I. and Benner, R.: Competition between biological and photochemical processes in the mineralization of dissolved organic carbon, Limnol. Oceanogr., 49, 117-124, 2004.

Ogawa, H. and Tanoue, E.: Dissolved organic matter in oceanic waters, J. Oceanogr., 59, 129-147, 2003.

Opsahl, S. and Benner, R.: Distribution and cycling of terrigenous dissolved organic matter in the ocean, Nature, 386, 480-482, 1997.

Opsahl, S. and Benner, R.: Photochemical reactivity of dissolved lignin in river and ocean waters, Limnol. Oceanogr., 43, 1297 1304, 1998.

Opsahl, S. and Zepp, R. G.: Photochemically-induced alteration of stable carbon isotope ratios in terrigenous dissolved organic carbon, Geophys. Res. Lett., 28, 2417-2420, 2001.

Osburn, C. L., Morris, D. P., Thorn, K. A., and Moeller, R. E.: Chemical and optical changes in freshwater dissolved organic matter exposed to solar radiation, Biogeochemistry, 54, 251-278, 2001.

Panetta, R. J., Ibrahim, M., and Gélinas, Y.: Coupling a hightemperature catalytic oxidation total organic carbon analyzer to an isotope ratio mass spectrometer to measure natural-abundance $\mathrm{d}^{13} \mathrm{C}$-dissolved organic carbon in marine and freshwater samples, Anal. Chem., 80, 5232-5239, 2008. 
Pullin, M. J., Bertilsson, S., Goldstone, J. V., and Voelker, B. M.: Effects of sunlight and hydroxyl radical on dissolved organic matter: Bacterial growth efficiency and production of carboxylic and other substrates, Limnol. Oceanogr., 49, 2011-2022, 2004.

Raymond, P. A. and Bauer, J. E.: DOC cycling in a temperate estuary: A mass balance approach using natural ${ }^{14} \mathrm{C}$ and ${ }^{13} \mathrm{C}$ isotopes, Limnol. Oceanogr., 46, 655-667, 2001a.

Raymond, P. A. and Bauer, J. E.: Riverine export of aged organic matter to the North Atlantic Ocean, Nature, 409, 497-499, $2001 b$.

Raymond, P. A., McClelland, J. W., Holmes, R. M., Zhulidov, A. V., Mull, K., Peterson, B. J., Striegl, R. G., Aiken, G. A., and Gurtovaya: Flux and age of DOC exported to the Artic Ocean: A carbon isotopic study of the five largest artic rivers, Global Biogeochem. Cy., 21, GB4011, doi:10.1029/2007GB002934, 2007.

Rossel, P. E., Vähätalo, A. V., Witt, M., and Dittmar, T.: Molecular composition of dissolved organic matter from a wetland plant (Juncus effusus) after photochemical and microbial decomposition (1.25 yr): Common features with deep sea dissolved organic matter, Org. Geochem., 60, 62-71, 2013.

Saliot, A., Derieux, S., Sadouni, N., Bouloubassi, I., Fillaux, J., Dagaut, J., Momzikoff, A., Gondry, G., Guillou, C., Breas, O., Cauwet, G., and Deliat, G.: Winter and spring characterization of particulate and dissolved organic matter in the Danube-Black sea mixing zone, Estuar. Coast. Shelf S., 54, 355-367, 2002.

Spencer, R. G. M., Stubbins, A., Hernes, P. J., Baker, A., Mopper, K., Aufdenkampe, A. K., Dyda, R. Y., Mwamba, V. L., Mangangu, A. M., Wabakanghanzi, J. N., and Six, J.: Photochemical degradation of dissolved organic matter and dissolved lignin phenols from the Congo River, J. Geophys. Res., 114, 1-12, 2009.

Stutter, M. I., Richards, S., and Dawson, J. C. C.: Biodegradability of natural dissolved organic matter collected from a UK moorland stream, Water Res., 47, 1169-1180, 2013.

Vähätalo, A. V. and Wetzel, R. G.: Long-term photochemical and microbial decomposition of wetland-derived dissolved organic matter with alteration of ${ }^{13} \mathrm{C}:{ }^{12} \mathrm{C}$ mass ratio, Limnol. Oceanogr., 53, 1387-1392, 2008 .
Vähätalo, A. V., Salonen, K., Salkinoja-Salonen, M., and Hatakka, A.: Photochemical mineralization of synthetic lignin in lake water indicates enhanced turnover of aromatic organic matter under solar radiation, Biodegradation, 10, 415-420, 1999.

Vähätalo, A. V., Salonen, K., Münster, U., Järvinen, M., and Wetzel, R. G.: Photochemical transformation of allochtonous organic matter provides bioavailable nutrients in a humic lake, Arch. Hydrobiol., 156, 287-314, 2003.

Vähätalo, A. V., Aarnos, H., Hoikkala, L., and Lignell, R.: Photochemical transformation of terrestrial dissolved organic matter supports hetero-and autotrophic production in coastal water, Mar. Ecol.-Prog. Ser., 423, 1-14, 2011.

Vodacek, A., Hogel, F. E., Swift, R. N., Yungel, J. K., Peltzer, E. T., and Blough, N. V.: The use of in situ and airborne fluorescence measurements to determine UV absorption coefficients and DOC concentrations in surface waters, Limnol. Oceanogr., 40, 411415, 1995.

Wang, X.-C., Chen, R. F., and Gardner, G. B.: Sources and transport of dissolved and particulate organic carbon in the Missippi River estuary and adjacent coastal waters of the northern Gulf of Mexico, Mar. Chem., 89, 241-256, 2004.

Williams, P. M. and Druffel, E. R. M.: Radiocarbon in dissolved organic matter in the central North Pacific Ocean, Nature, 330, 246-248, 1987.

Xiao, Y.-H., Sara-Aho, T., Hartikainen, H., and Vähätalo, A. V.: Contribution of ferric iron to light absorption by chromophoric dissolved organic matter, Limnol. Oceanogr., 58, 653-662, 2013.

Yu, J., Elderfield, H., and Piotrowski, A. M.: Seawater carbonate ion- $\mathrm{a}^{13} \mathrm{C}$ systematics and applications to glacial-interglacial North Atlantic ocean circulation, Earth Planet. Sci. Lett., 271, 209-220, 2008.

Zepp, R. G.: Light and environmental chemistry: Influence of changing solar radiation on aquatic photoreactions, IUVA News, 7, 9-14, 2005. 